\title{
CASE HISTORIES: KARST SUCCESSES AND FAILURES IN THE EASTERN UNITED STATES
}

Walter G. Kutschke

DiGioia Gray \& Associates, 570 Beatty Road, Monroeville,PA 15146, USA, wkutschke@digioiagray.com

\begin{abstract}
A basic understanding of karst development and sinkhole formation is that water drives everything in karst. Design efforts need to consider this basic karst principle before undertaking any meaningful design. Another aspect of karst often overlooked by engineers is that sinkholes are direct input points where surface water can access the karst aquifer and impact water quality and hibernacula of caving dwelling species. Site characterization activities in karst typically only involve test borings and geophysical methods. These methods provide a valuable snap-shot in time of subsurface conditions, which is important, but they provide no insight into groundwater fluctuations. Case histories involving roadway, pipeline and building projects demonstrate the successes and failures of geotechnical engineering over karst. Several case histories indicate the detrimental impact of altering subsurface water conditions which can result in increased subsurface erosion and new sinkhole development. Case histories also underscore the importance of controlling surface water and when not properly considered the result can be sudden and catastrophic sinkhole development. Experience gained from new and forensic karst projects located along the eastern United States with aggregate construction costs approaching \$1 billion all had a common theme; understand and control surface and subsurface water.
\end{abstract}

\section{Introduction}

Karst is the German form of the Slavic word "kras", which means a "bleak waterless place" and dates back to the 19th century where it referred to an approximate 500 meter high limestone plateau situated in Slovenia. Similar terrain has since been termed karst, which is defined as a type of topography formed over limestone, dolomite or gypsum by dissolving or solution, and that is characterized by closed depressions or sinkholes, caves and underground drainage (Field, 2002).

Karst is a unique and challenging environment that can offer powerful and sudden surface expressions in the form of sinkholes. Karst features such as sinking streams, swallets, karst windows, and blind valleys are among some of the many engineering challenges when considering site development. Karst owes it origins to water; water drives everything in karst. Failure to understand surface and subsurface water conditions will likely lead to exacerbating site conditions with the consequence of continued sinkhole development.

\section{Karst Origins and the Role of Water}

Limestone, a sedimentary rock consisting of at least 50 percent calcium carbonate $\left(\mathrm{CaCO}_{3}\right)$, is perhaps the most commonly associated bedrock with karst (Field, 2002). In general, the origin of limestone begins from the precipitation of bicarbonates that generally occur in a sea water environment. Bicarbonate precipitation occurs from direct chemical precipitation as well as from sedimentation of the skeletal remains of marine organisms. Consolidation of carbonate sediments along with other mineral impurities (e.g., clays, silts, sands, et cetera) result in a reduction of porosity and void ratio. Environmental changes may also result in the re-solution and re-precipitation of the carbonates that remove most of the identity of the original particles. The varied sedimentation and post-sedimentation history of limestone make it one of the most varied of all sedimentary rocks (Sowers, 1996).

The development of karst is a natural process driven by water. Water that percolates downward through soil and unconsolidated sediment overlying limestone tends to become more acidic as it absorbs $\mathrm{CO}_{2}$. In simple terms, $\mathrm{CO}_{2}$ dissolved in water partially disassociates and forms $\mathrm{H}_{2} \mathrm{CO}_{3}$, a weak carbonic acid. The weak acid reacts with the calcite to form soluble $\mathrm{Ca}\left(\mathrm{HCO}_{3}\right)_{2}$. Dissolution rates generally occur at a rate of a few millimeters per 100 years in the eastern United States and the rate can increase dramatically in tropical climates (Sowers, 1996; Waltham and Fookes, 2005). The dissolution process can be exacerbated or terminated by seemingly subtle changes in temperature, $\mathrm{pH}$, and dissolved ion concentrations. For example, limestone dissolution rates in a tropical environment may reach $20 \mathrm{~mm}$ per 100 years whereas limestone placed in distilled water is less soluble than silica (Sowers, 1996). Interested readers are encouraged to refer to White (1988) for detailed discussion regarding the chemistry of carbonate dissolution.

As groundwater drains downward and pools along the limestone surface, lateral water flow will inevitably reach a fracture, bedding, or joint feature. These features allow 


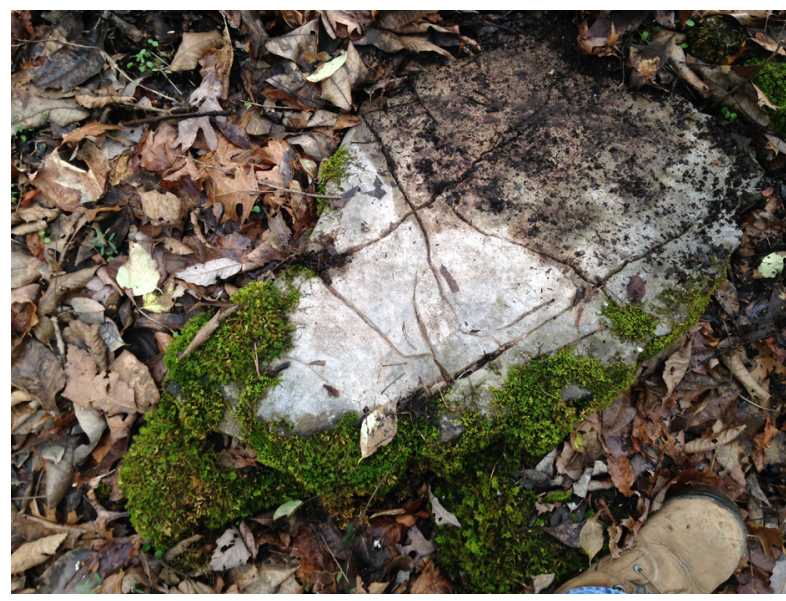

Figure 1. Solution grooving in limestone

the continued downward water migration to an erosional base level that creates preferential pathways through a self-accelerating process. Figure 1 presents a typical example of solution grooving associated with limestone dissolution. This grooving, although exposed at the surface, could result in the development of preferential drainage pathways over geologic time through a similar process in the subsurface.

Subsurface water under differential head conditions can transport soluble components while insoluble components remain (i.e., gravels, sands, silts and clays deposited with the carbonate of the original rock). This process results in a residual soil strength profile that is typically inverted compared to that of deposited soils as the residual soil in karst becomes softer with increasing depth, usually most pronounced within 2 to 4 meters above the limestone (Sowers, 1996). Residual soil in karst is also reverse of typical soil deposits as the oldest soil in karst is at the top of the residual layer and the youngest is at the bottom of the residual layer; an important concept often misunderstood when evaluating site conditions.

Over geologic time, a complex and highly developed network of solution conduits, voids, and irregular bedrock surface develops, which is collectively known as "epikarst". Significant water storage and flow can occur here and this is where most of engineering challenges exist. Williams (2008) notes that epikarst can exhibit secondary porosity between $10 \%$ to $30 \%$ compared to less than $2 \%$ for the main body of unweathered limestone. Figure 2 provides a typical example of exposed epikarst. Epikarst thickness is typically 3 to 10 meters deep, although the characteristics can vary considerably and zones of several 100 meters deep have been noted (Williams, 2008). However, since soil is the

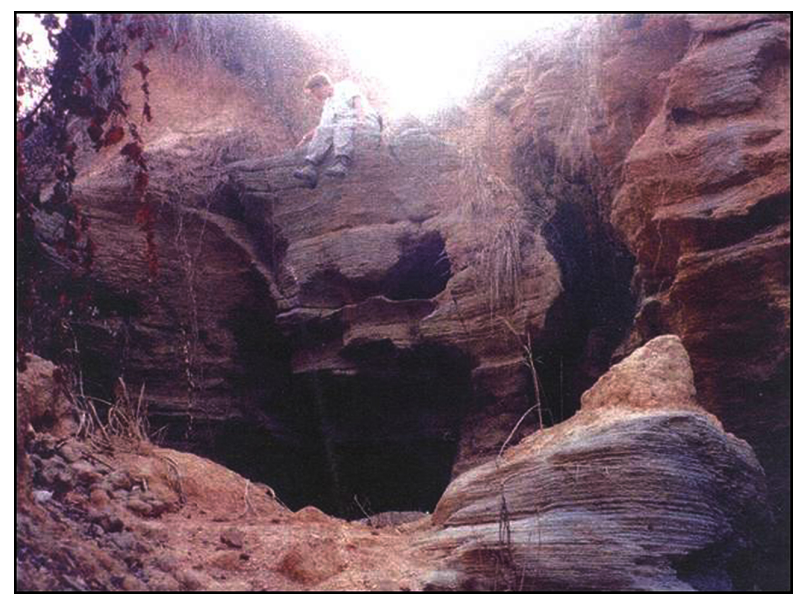

Figure 2. Exposed epikarst

main source of $\mathrm{CO}_{2}$ production, the greatest expenditure of chemical energy occurs near the bedrock surface and this will tend to limit epikarst depth as the water becomes saturated with dissolved minerals at depth. Fords and Williams (2007) note that about $70 \%$ of solutional denudation is typically accomplished within the top 10 meters and corrosion attack gradually diminishes with distance from the $\mathrm{CO}_{2}$ supply.

\section{Sinkhole Classifications}

Sinkholes result from two different processes, either the erosion and transport of surficial materials along solution pathways or the collapse of roofs over cavities. Sinkholes are generally classified into five types, namely (Culshaw and Waltham, 1987; Beck 1991; Waltham and Fookes 2005):

1) Solution sinkhole;

2) Cave collapse sinkhole;

3) Buried sinkhole;

4) Cover-Subsidence sinkhole; and

5) Cover-Collapse sinkhole.

Each of the five sinkhole types has its own discrete mechanism of formation, but they are all ultimately the result of water (Beck, 1991; Lowe and Waltham, 2002). The first two sinkhole types (i.e., solution and cave collapse) occur in rock and are essentially stable features except that open solution conduits or caves must exist beneath them (Waltham and Fookes, 2005). The natural event of rock collapse is rare (Newton, 1987). Sowers (1996) indicates that of the hundreds of investigated sinkholes, perhaps only 2 or 3 were rock collapse and they were located in the Caribbean Islands. Beck (1991) also notes that of the 1,700 sinkholes that developed in Florida in approximately a 25 -year period, none were bedrock collapse. Karst bedrock collapse features may 
be more common in seismically active regions with occasional strong ground motions, such as the Caribbean.

The greater hazard in karst is associated with sinkholes that develop in the overburden created as a direct result of subsurface erosion of sediment into the underlying solution conduits. An important concept is that sinkholes do not occur randomly; they occur where geologic conditions have created solution pathways in the underlying soluble rock, and they involve the last three sinkhole types noted above (i.e., buried, coversubsidence and cover-collapse sinkholes). Although the karst hydrogeologic regime is extremely complex, sinkhole formation is relatively straightforward and is driven by water. Solution conduits from karstification provide a channel for water to move and to erode cover sediment into deeper dissolved voids.

\section{Basic Karst Principle}

Personal experience and published literature readily indicate that conditions which increase the downward movement of water through the soil overburden can initiate or increase sinkhole activity in karst regions. Three factors are leading contributors to sinkhole development in areas underlain by karst (Newton, 1987; Sowers, 1996; Hubbard 2001; Waltham and Fookes, 2005):

1) Increasing the infiltration of water at the ground surface,

2) Depressing the piezometric level in the rock significantly below the soil-rock interface to provide high exit gradients for downward draining water, and

3) Repeated fluctuation of the groundwater from well above to well below the soil-rock interface.

These leading contributors to sinkhole development need to be considered when engineering over karst and they form the basic karst principle: understand and control surface and subsurface water. Failure to neglect this basic karst principle will inevitability result in continued and perhaps accelerated sinkhole occurrence.

The literature has ample documentation on the mechanics of sinkhole formation and interested readers are encouraged to read Beck (1991) or Waltham and Fookes (2005) for further details.

\section{Karst Case Histories}

The development of karst is a natural process driven by water over geologic time (i.e., millions of years). However, it is the downward movement of water through the overburden and epikarst that can cause subsurface erosion of the overlying soil mantle and sinkhole development within project life cycles. Therefore sinkholes do not occur randomly, they occur where geologic conditions have created solution pathways in the epikarst that allow water to cause subsurface erosion.

Sinkholes noted herein are generally of the covercollapse type as these tend to be the most catastrophic. Waltham and Fookes (2005) and Newton (1987) note that many sinkholes are created as a direct result of human activities, particularly those that affect surface drainage or groundwater flow. Newton (1987) also notes that the formation of new sinkholes under natural conditions is relatively rare during the course of human lifetime, while sinkholes induced by engineering works are abundant. The abundance of these sinkholes is due to a lack of understanding of the basic karst principle noted herein as will be demonstrated by the following case studies.

Understand Subsurface Water Conditions Understanding subsurface drainage conditions is vital to developing appropriate karst remediation methods as exampled by a grout program that was as part of a rail improvement project located in Maryland. Review of structural geology data for this project indicated that the grout program essentially created a subsurface cut-off wall parallel to the synclinal axis (or perpendicular to the bedding dip). Upon completion of grouting, a monitoring well near the rail recorded a water elevation increase of 12.2 meters over a three-month period as subsurface water drained down-gradient along the bedding dip and became dammed by the grout wall. This was the largest head increase noted in the monitoring well during the five-year monitoring period. Unfortunately, a power failure in the instrument was not repaired until four months later when the water was back to its normal level. It is the author's opinion the large head drop occurred because of an apparent occluded conduit that softened under the head increase and allowed rapid subsurface water drainage causing subsurface erosion. Soil raveling likely occurred and shortly thereafter, a covercollapse sinkhole developed that measured 34 meters by 15 meters and was 11 meters deep. Refer to Figure 3 for a picture of the sinkhole. This sinkhole developed over an approximate five month period. The sinkhole was backfilled with large stone and an emergency grouting contractor began repairs. However, during the grouting operation, another sinkhole developed directly underneath the grouting equipment. The additional collapse would claim a small front-end loader, toolbox and site supplies before final remediation; site personal were not injured (Kutschke, et al. 2005).

The sinkhole noted in Figure 3 developed as a result human activities that changed subsurface drainage 
conditions. Engineers seem to readily approach karst with various forms of grout programs and neglect to consider its impact on subsurface water. By occluding or otherwise altering subsurface drainage, one has to consider where subsurface water will go now that the pre-existing subsurface drainage path has been altered. Assuming that no other conditions have changed which would otherwise alter subsurface water recharge (which is often the case with grout programs), saturation of the peripheral area will increase subsurface drainage to adjacent epikarst drains and / or softening of occluded conduits with the consequence of new sinkhole development (Hubbard, 2001).

The importance of subsurface water and its ability to cause subsurface erosion is demonstrated by monitoring wells at large resort in Florida. Handfelt and Attwooll (1988) explain that this site is situated over 20 to 30 meters of mature karst (Waltham and Fookes, 2005) and that monitoring wells switch water pumping where a local water table decline is detected in an attempt to actively manage the water table elevation. The intent of this program is to minimize differential head conditions that would cause water movement with the potential impact of subsurface erosion.

Conversely, dewatering activities such as those conducted by quarries, significantly alter subsurface water conditions with the consequence of new sinkhole development. This action depresses the piezometric level significantly below the soil-rock interface to provide high exit gradients for downward draining water. This condition is favorable for new sinkhole formation as Kutschke et al (2005) notes an aggressive sinkhole occurrence interval of eight sinkholes per year in an area surrounding a rock quarry. The literature has many other examples of dewatering that leads to new sinkhole formation and subsequent legal action to define the zone of influence (Quinlan, 1986; Gary, 1999).

So where does the subsurface water go? As Hubbard (2001) notes, using grout to seal a solution throat has the potential to restrict or occlude the under draining conduit, which can lead to back-flooding, quick soil conditions and new sinkhole formation. Restricting the subsurface flow into the existing subsurface drains by grouting merely diverts the subsurface flow elsewhere. Without an understanding of the process driven sinkhole hazards, site development and associated design activities will continue to exacerbate sinkhole development. Mellet and Maccarillo (1989) underscore this basic karst concept in which they conclude that grouting some areas will only divert subsurface flow elsewhere into unknown areas with the likely consequence of new sinkholes development.

To help visualize this concept of subsurface water flow, Figure 4 presents a typical construction site with active grading over karst. Excavation has removed significant portions of the overburden to expose the top of rock. Figure 5 presents an oblique view of the idealized top of rock based on extensive geophysical investigation where the "dots" represent known sinkhole locations. Although the projects noted in Figure 4 and Figure 5 are not related to each other, they display the same basic characteristics of karst, that being an irregular rock surface. One could easily imagine that with no change made to subsurface drainage or subsurface recharge that occluding the sinkhole throat with a grout program would result in peripheral pooling. As the peripheral pool(s) rise and saturate new areas, karst features that were otherwise

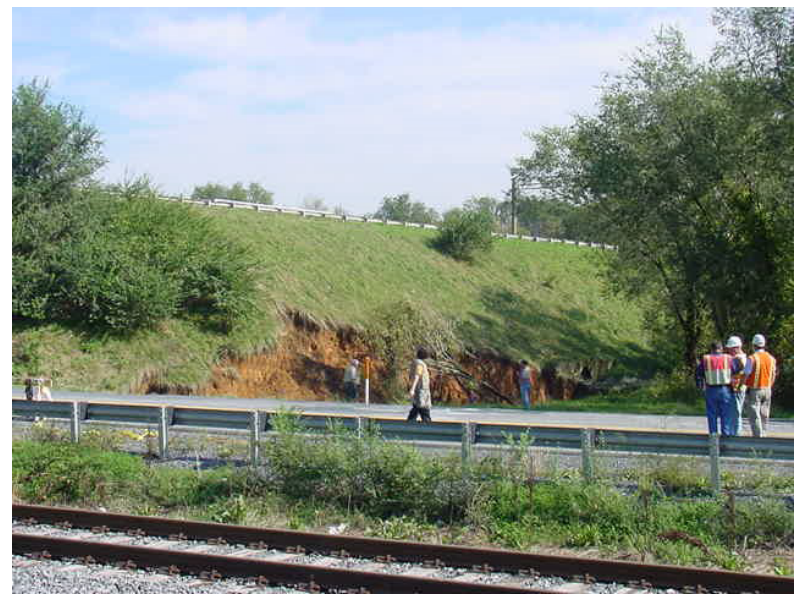

Figure 3. Cover-collapse sinkhole due to changed subsurface drainage conditions. Note proximity of railway to sinkhole

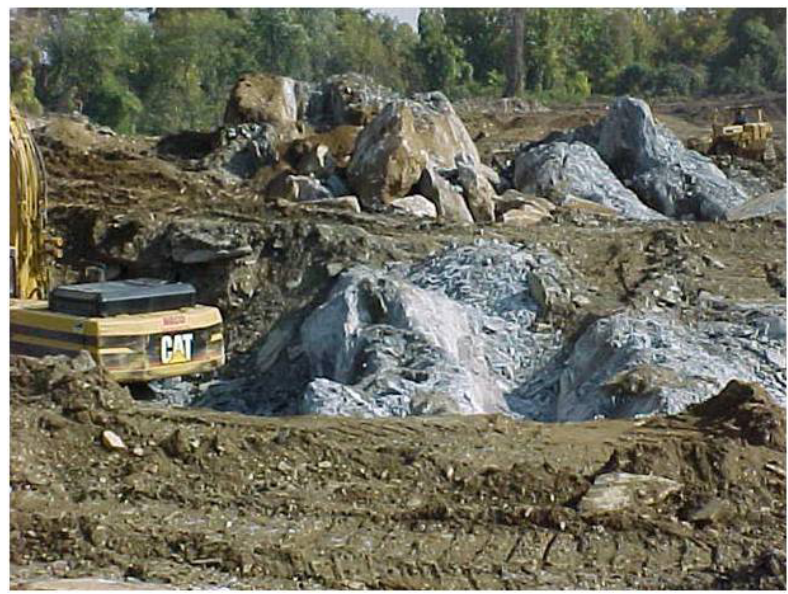

Figure 4. Typical excavation in karst 


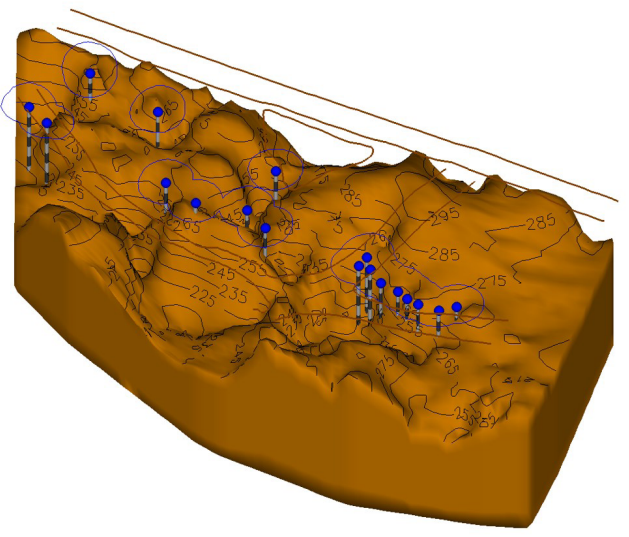

Figure 5. Idealized top-of-rock surface in karst based on geophysical test methods

abandoned or occluded would become saturated and could provide new preferential pathways for subsurface erosion, as evidenced by Figure 3 .

Sinkholes mark epikarst drains and they also serve to mark preferential subsurface drainage pathways. Sinkholes develop where solutional pathways exist in the underlying rock. Efforts should be made to understand sinkhole formation, the hydraulic conditions that cause the erosion, and only then can logic based approaches be developed to remediate karst.

Understand Surface Water Conditions. Human activities, particularly those that affect surface drainage are documented to have a direct and significant effect on triggering sinkhole collapse (Newton, 1987; Sowers, 1996; Waltham and Fookes, 2005; and Kutschke, et al. 2005). Figure 6 provides a typical example that underscores the basic karst principle of what happens when surface water is not properly controlled. The literature also provides several examples that demonstrate how large downward water gradients lead to sinkhole development.

- Sowers (1996) provides one of the most catastrophic examples of the effects of increasing surface water drainage resulting in new sinkhole development. Flooding resulted when a tropical storm generated flood water depths as high as 6.5 meters near Albany, Georgia in July 1994. This flooding resulted in more than 300 new sinkholes with the majority of them occurring in a $14 \mathrm{sq} \mathrm{km}$ area. The largest measured 44 by 21 meters.

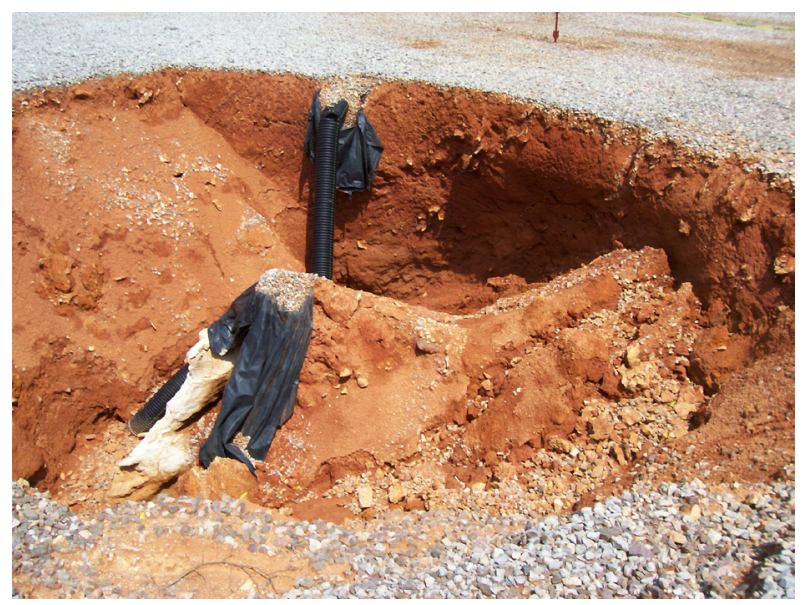

Figure 6. Sinkhole development as a result of concentrated surface water

- Jammal, et al (2010) provide a case history of multiple sinkhole developments in a ten hectare single cell storm water retention basin located in Florida. They note that compaction grouting was used to stabilize known sinkholes. However, two dozen "spontaneous sinkholes" developed after several rain events and a heavy storm that filled $40 \%$ of the design storage volume. Repairs consisted of a sand infill due to concerns with environmental degradation of the karst aquifer (i.e., sand provides some filtration). Subsequently, after a heavy rain event that filled $60 \%$ of the design capacity, thirty sinkholes developed. Jammal, et al (2010) notes that the pond bottom was expected to be approximately 3 to 6 meters above the limestone surface and about 8 meters above the piezeometic level within the limestone; the site allowed for high exit gradients at the soil-rock interface.

- Bonaparte and Berg (1987) note sinkhole development along a portion of roadway in Pennsylvania, which first documented karst features in the early 1960's and which developed into a perennial problem by the 1970's. One cover-collapse sinkhole that directly impacted the roadway had initial dimensions of 30 meters by 60 meters. Bonaparte and Berg (1987) indicate that development of the area resulted in increased surface water infiltration, rerouting of a surface stream and a 60 to 100 meter drop in the water table caused by ground-water pumping for an underground zinc mine. 
- Heung and Gobin (2010) note that roadway construction induced sinkholes that were the result of altered pathways of groundwater recharge at the soilrock interface (i.e., epikarst) for the construction of a new roadway in Florida. They also note that after project completion, new sinkholes "occurred only in retention ponds and swales during rainy seasons."

Newton (1987) and Waltham and Fookes (2005) provide many other examples of how civil engineering works changed surface water conditions with the consequence of new sinkhole development.

The case histories demonstrate the important concept of understanding surface water. All of the projects had either large concentrations or altered drainage patterns of surface flow. The real deterrent to sinkhole formation is the control of surface water and the prudent application of sinkhole repair methods. If an area is not undergoing active sinkhole development, efforts must be made to maintain the existing surface and subsurface groundwater conditions. If groundwater conditions are altered, new flow paths will likely develop with the result of new sinkhole development as the karst system erodes a new "equilibrium."

\section{Environmental Impacts}

Circulation of groundwater through karst is significantly different from water circulation through non-karst settings. Recharge of karst aquifers can be direct input into epikarst drains and by percolation of rainwater through a network of joints. Stephenson and Beck (1995) present an extensive review of the stormwater discharge from highway runoff in karst areas. Soil thickness is an important variable as a thin or nonexistent soil cover offer little to no immobilization for many runoff pollutants and result in direct input into the karst aquifer. Karst groundwater systems can transport sediment and containments virtually unimpeded into an aquifer, cave, or spring system due to the rapid recharge rate and lack of filtering. Figure 7 was obtained from a down-the-hole camera in a completed test boring that encountered a water filled void. Careful examination of the image will reveal a crustacean "speleologist" that apparently found his way into a solution conduit from a nearby stream.

New construction in karst must consider environmental impacts. For example, directing highway runoff into known karst features can degrade water quality. Conversely, redirecting run-off from karst features can

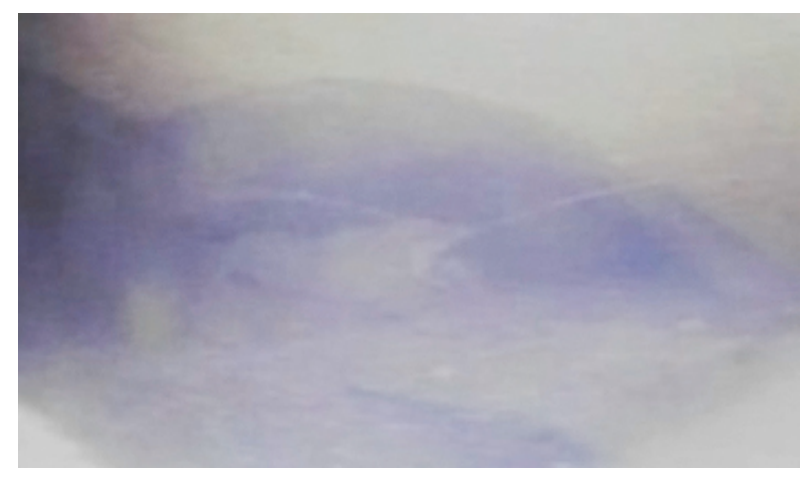

Figure 7. Crustacean in Karst Conduit

have a negative impact on aquatic species within the karst system by decreasing the quantity of water entering the system. As noted, if a karst site is not undergoing active sinkhole development or environmental degradation, then one should try to minimize changes to surface and subsurface water conditions. That being said and with proper site knowledge and environmental controls, innovative solutions can be applied to protect baseline karst system integrity.

Stephenson, et al. (1997) present a case study in which highway storm water runoff was directed into a sinkhole as part of the storm water management program in Tennessee. The initial flush of storm water went through a filter system consisting of peat, sand, and limestone to remove contaminants by sedimentation, filtration and adsorption. The tested sorption/filtration systems achieved contaminant removal efficiencies in the range of 90 to $99 \%$. A similar program was going to be conducted in Maryland on a project that the author had direct involvement with, but the program was canceled at the last minute due to lack of funding. Duffy (2008) also made use of existing sinkholes for stormwater management for a new hospital in Indiana. Special measures included oil-water separators to minimize petroleum hydrocarbon contaminants from reaching the subsurface water.

\section{Engineering Over Karst}

The variability of karst makes characterization and identification of features extremely difficult. Characterization for geotechnical engineering efforts in karst must include methods that provide understanding of surface and subsurface water as well as site activity regarding sinkhole occurrence intervals; this knowledge must be developed before assessing any karst project.

Test borings and geophysical methods are tools that will help characterize localized areas, but one must be extremely careful in relying on this data alone. 


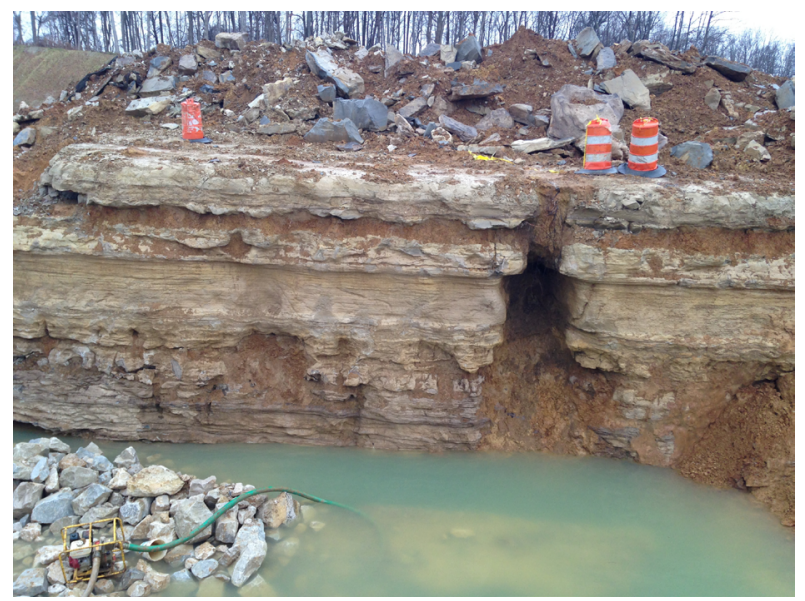

Figure 8. Difficulties of Site Characterization in Karst

Construction within karst will encounter unexpected challenges no matter how much time and money is invested (or wasted) in an effort to fully characterize all karst features; karst will never fully reveal itself. For example, consider a typical roadway project involving several kilometers of roadway in Indiana with multiple test borings developed along cross sections. Refer to Figure 8 and consider the odds of encountering this feature with a test boring program (which this project did not encounter). This is not an idealized or isolated case when dealing with karst as the author could provide multiple examples of unexpected karst features. However, to properly address these types of challenges in the field, one must have an understanding of the basic karst principles noted herein. Proper site characterization must not only involve our traditional geotechnical tools, but it must involve methods to assess subsurface water conditions. Water level monitoring of both elevation as well as temperature and correlating that data to precipitation are powerful tools to begin understanding karst. Fluctuations in subsurface water begin to provide an understanding of potential risk for subsurface erosion. Variations in temperature provide insight into subsurface water recharge and water movement. Relative risk of sinkhole collapse can also be calculated with a high degree of certainty with a proper site characterization program (Zhou, et al. 2003; Kutschke, et al. 2005).

Sinkhole remediation from a geotechnical engineering perspective is generally undertaken to alleviate subsidence hazards. It is important to note that most cover-collapse sinkholes are associated with epikarst drains where water movement has eroded sediments. Common methods to remediate these sinkholes involve creating an obstruction in the sinkhole throat, which consists of an inverse aggregate graded filter or a grout plug (Sowers, 1996; Hubbard, 2001; Duffy, 2008;
Kutschke, et al. 2014). Prudent use of these treatments requires consideration of surface water and subsurface water conditions. Although a grout plug is thought to be the most effective means to repair a sinkhole, it is not the most effective means to deter future sinkhole development. Sinkholes develop because of subsurface water movement causes erosion; remediation should consider allowing the water to flow along its known preferential path but not let the water cause erosion. Plugging the preferential pathway merely diverts the water to surrounding areas with unknown consequences. The use of inverse-graded filters to seal a sinkhole throat and allow the continued movement of water should be given serious consideration. However, solutions may require grout due to site constraints, although this does not alleviate understanding the ramifications. Consideration should also be given to the use of geomembrane lined drainage ditches and geomembrane lined storm water retention basins with pump stations to control surface water.

\section{Summary}

Every karst site is unique. However, lessons learned from review of case histories all have a commonality, that being water. Site characterization must focus efforts to understand the cause of sinkhole occurrence along with surface and subsurface water over seasonal conditions. Given the many site characterization tools available today, simple methods that provide a snap-shot in time are not sufficient. Water is the driving force in karst and sinkhole formation, and one must not become blind to the process operating in the subsurface over time. Occluding known epikarst drains, altering surface drainage, and lowering groundwater are among the many contributors that could lead to sudden and catastrophic karst expressions. Understand the water, and you will begin to appreciate the challenges of karst.

\section{References}

Beck B. 1991. On calculating the risk of sinkhole collapse. Proceedings of the Appalachian Karst Symposium. Radford, VA; National Speleological Society, Huntsville, AL, 231-236.

Bonaparte R, Berg R. 1987. The use of geosynthetics to support roadways over sinkhole prone areas. 2nd Multidisciplinary Conf. on Sinkholes and the Environmental Impacts of Karst, Orlando, FL, 437-445.

Culshaw M, Waltham A. 1987. Natural and artificial cavities as ground engineering hazards. Quarterly Journal of Engineering Geology, 20: 139-150.

Duffy P. 2008. Foundation design and site development for a new hospital over a complex karst system. 
11th Multidisciplinary Conf. on Sinkholes and the Engineering and Environmental Impacts of Karst, GSP No. 183, ASCE, Reston, VA.

Field M. 2002. A lexicon of cave and karst terminology with special reference to environmental karst hydrology. EPA/600/R-02/003.

Ford D., Williams P. 2007. Karst hydrogeology and geomorphology", John Wiley \& Sons, Ltd, Hoboken, NJ.

Gary M. 1999. Maryland's zone of dewatering influence law for limestone quarries. In: Beck BF. Pettit AJ and Herring JG (Eds.) Hydrology and Engineering Geology of Sinkholes and Karst, Balkema: Rotterdam, 273-277.

Handfelt L., Attwooll W. 1988. Exploration of karst conditions in central Florida, ASCE GSP 14: 4052.

Heung W., Gobin R. 2010. A case history of construction induced sinkholes. Proc. of Geo-Florida 2010, Advances in Analysis, Modeling and Design, GSP No. 199 (CD-ROM), ASCE, Reston, VA.

Hubbard D. 2001. Hazard and resource considerations in site development in Virginia karst. Proc. Foundations and Ground Improvement, ASCE, Reston, Virginia.

Jammal S., Casper J., Sallam A. 2010. Development mechanism and remediation of multiple spontaneous sinkholes: A case history. Proc. of Geo-Florida 2010, Advances in Analysis, Modeling and Design, GSP No. 199 (CD-ROM), ASCE, Reston, VA.

Kutschke W., Miller S., Zhou W., Beck B. 2005. Site characterization and geotechnical roadway design over karst: Interstate 70, Frederick County, Maryland. Proceedings of the 10th Multidisciplinary Conference on Sinkholes and the Engineering and Environmental Impacts of Karst, GSP No. 144, ASCE, Reston, VA.

Kutschke W., Conner G., Krothe J. 2014. Site characterization and geotechnical roadway design over karst: Interstate 69, Greene and Monroe Counties, Indiana. Proceedings of Geo-Congress 2014, Innovative Rock Characterization and Analyses, GSP No. 234, ASCE, Reston, VA.

Lowe D., Waltham T. 2002. Dictionary of karst and caves. British Cave Research Association Cave Studies, 10: 1-40.

Mellett, J., Maccarillo B. 1989. Highway engineering aspects of karst terrane near Alpha, New Jersey. Proceedings of the 3rd Multidisciplinary Conference on Sinkholes. St. Petersburg, Florida.

Moore H. 1987. Sinkhole development along 'untreated' highway ditches in east Tennessee. Proceedings of 2nd Multidisciplinary Conference on Sinkholes and the Engineering Environmental Impacts of Karst. Orlando, Florida.

Newton J. 1987. Development of sinkholes resulting from man's activities in the eastern United States. USGS Circular 968, Denver, CO.

Quinlan J. 1986. Legal aspects of sinkhole development and flooding in karst terranes. Environmental Geology and Water Science, 8:41-61.

Sowers G. 1996. Building on sinkholes. ASCE Press, New York, New York.

Stephenson J., Zhou W., Beck B., Green T., Smoot J., Turpin A. 1997. Management of highway stormwater runoff in karst areas - baseline monitoring and design of a treatment system for a sinkhole at the I-40/I-640 interchange in eastern Knoxville, TN. Proc. of the 48th Highway Geology Symposium, Knoxville, TN.

Stephenson J., Beck B. 1995. Management of the discharge quality of highway runoff in karst areas to control impacts to ground water - a review of relevant literature. Proc. of 5rd Multidisciplinary Conference on Sinkholes and the Engineering Environmental Impacts of Karst, Gatlinburg, TN.

Waltham A., Fookes P. 2005. Engineering classification of karst ground conditions. Speleogenesis and Evolution of Karst Aquifers. 3(1): 1-20.

White W. 1988. Geomorphology and hydrology of karst terrains. Oxford University Press, New York, New York.

Williams P. 2008. The role of the epikarst in karst and cave hydrogeology; a review", International Journal of Speleology, 37(1): 1-10.

Zhou W., Beck B., Adams A. 2003. Sinkhole risk assessment along highway I-70 near Frederick, Maryland." 9th Multidisciplinary Conference on Sinkholes and the Engineering and Environmental Impacts of Karst, ASCE, 591-604. 